NASA/TM-2000-209891, Vol. 70

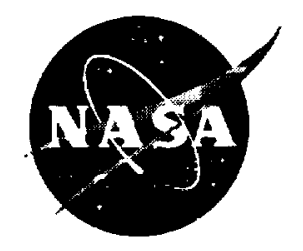

Technical Report Series on the Boreal Ecosystem-Atmosphere Study (BOREAS)

Forrest G. Hall and Jaime Nickeson, Editors

Volume 70

BOREAS RSS-17 Dielectric

Constant Profile Measurements

K.C. McDonald, R. Zimmerman, and J.B. Way

National Aeronautics and

Space Administration

Goddard Space Flight Center

Greenbelt, Maryland 20771 


\section{The NASA STI Program Office ... in Profile}

Since its founding, NASA has been dedicated to the advancement of aeronautics and space science. The NASA Scientific and Technical Information (STI) Program Office plays a key part in helping NASA maintain this important role.

The NASA STI Program Office is operated by Langley Research Center, the lead center for NASA's scientific and technical information. The NASA STI Program Office provides access to the NASA STI Database, the largest collection of aeronautical and space science STI in the world. The Program Office is also NASA's institutional mechanism for disseminating the results of its research and development activities. These results are published by NASA in the NASA STI Report Series, which includes the following report types:

- TECHNICAL PUBLICATION. Reports of completed research or a major significant phase of research that present the results of NASA programs and include extensive data or theoretical analysis. Includes compilations of significant scientific and technical data and information deemed to be of continuing reference value. NASA's counterpart of peer-reviewed formal professional papers but has less stringent limitations on manuscript length and extent of graphic presentations.

- TECHNICAL MEMORANDUM. Scientific and technical findings that are preliminary or of specialized interest, e.g., quick release reports, working papers, and bibliographies that contain minimal annotation. Does not contain extensive analysis.

- CONTRACTOR REPORT. Scientific and technical findings by NASA-sponsored contractors and grantees.
- CONFERENCE PUBLICATION. Collected papers from scientific and technical conferences, symposia, seminars, or other meetings sponsored or cosponsored by NASA.

- SPECIAL PUBLICATION. Scientific, technical, or historical information from NASA programs, projects, and mission, often concerned with subjects having substantial public interest.

- TECHNICAL TRANSLATION.

English-language translations of foreign scientific and technical material pertinent to NASA's mission.

Specialized services that complement the STI Program Office's diverse offerings include creating custom thesauri, building customized databases, organizing and publishing research results ... even providing videos.

For more information about the NASA STI Program Office, see the following:

- Access the NASA STI Program Home Page at http://www.sti.nasa.gov/STI-homepage.html

- E-mail your question via the Internet to help@sti.nasa.gov

- Fax your question to the NASA Access Help Desk at (301) 621-0134

- Telephone the NASA Access Help Desk at (301) 621-0390

- Write to:

NASA Access Help Desk

NASA Center for AeroSpace Information

7121 Standard Drive

Hanover, MD 21076-1320 
NASA/TM-2000-209891, Vol. 70

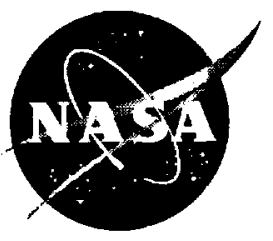

\section{Technical Report Series on the Boreal Ecosystem-Atmosphere Study (BOREAS)}

Forrest G. Hall and Jaime Nickeson, Editors

\section{Volume 70}

\section{BOREAS RSS-17 Dielectric Constant Profile Measurements}

Kyle C. McDonald, Jet Propulsion Laboratory, Pasadena, California

Reiner Zimmerman, Bayreuth Institute for Terrestrial Ecosystem Research (BITOEK), University of Bayreuth, Bayreuth, Germany

JoBea Way, Jet Propulsion Laboratory, Pasadena, California

National Aeronautics and

Space Administration

Goddard Space Flight Center

Greenbelt, Maryland 20771 
Available from:

NASA Center for AeroSpace Information

7121 Standard Drive

Hanover, MD 21076-1320

Price Code: A17
National Technical Information Service 5285 Port Royal Road Springfield, VA 22161

Price Code: A10 


\title{
BOREAS RSS-17 Dielectric Constant Profile Measurements
}

\author{
Kyle McDonald, Reiner Zimmermann, JoBea Way
}

\section{Summary}

The BOREAS RSS-17 team acquired and analyzed imaging radar data from the ESA's ERS-1 over a complete annual cycle at the BOREAS sites in Canada in 1994 to detect shifts in radar backscatter related to varying environmental conditions. This data set consists of dielectric constant profile measurements from selected trees at various BOREAS flux tower sites. The relative dielectric constant was measured at $\mathrm{C}$-band (frequency $=5 \mathrm{GHz}$ ) as a function of depth into the trunk of three trees at each site. Measurements were made during April 1994 with an Applied Microwave Corporation field PDP fitted with a $0.358-\mathrm{cm}(0.141$-inch $)$ diameter coaxial probe tip. The data are available in tabular ASCII files.

\section{Table of Contents}
1) Data Set Overview
2) Investigator(s)
3) Theory of Measurements
4) Equipment
5) Data Acquisition Methods
6) Observations
7) Data Description
8) Data Organization
9) Data Manipulations
10) Errors
11) Notes
12) Application of the Data Set
13) Future Modifications and Plans
14) Software
15) Data Access
16) Output Products and Availability
17) References
18) Glossary of Terms
19) List of Acronyms
20) Document Information

\section{Data Set Overview}

\subsection{Data Set Identification \\ BOREAS RSS-17 Dielectric Constant Profile Measurements}

\subsection{Data Set Introduction}

The dielectric constant provides an indication of how a material responds in an electric field. Thus, it is useful to quantify this property in order to interpret radar remote sensing signatures. When considering the microwave frequency spectrum, the dielectric constant of liquid water is much higher than that of other components of a natural landscape. Thus, variations in the amount (moisture content) and state (frozen vs. thawed) of water in a vegetation canopy can significantly affect radar backscatter. The relative dielectric constant was measured as a function of depth into the trunks of three trees at each of seven treed BOReal Ecosystem-Atmosphere Study (BOREAS) tower sites. In the Northem Study Area (NSA), measurements were taken at the Old Black Spruce (OBS), Young Jack Pine (YJP), 
and Old Jack Pine (OJP) sites. In the Southern Study Area (SSA), measurements were taken at the YJP, OJP, OBS, and Old Aspen (OA) sites. An Applied Microwave Corporation C-band field portable dielectric probe (PDP) was used to measure these data. Profiles were obtained during April 1994, shortly after the trees thawed.

\subsection{Objective/Purpose}

These measurements were taken to assist with interpretation of radar backscatter measurements obtained with the Earth Resource Satellite-1 (ERS-1) Synthetic Aperture Radar (SAR). The dielectric constant of woody vegetation varies dramatically as the vegetation transitions from a frozen to a thawed state. Because radar backscatter responds to changes in the dielectric constant, these measurements were obtained to verify that the trees had undergone the spring thaw transition. These data may also be used as parameter inputs to radar backscatter models to assist in interpretation of radar remote sensing measurements obtained at the BOREAS sites.

\subsection{Summary of Parameters and Variables}

Each line provides the real and imaginary parts of the relative dielectric constant at a single depth in the trunk of a selected tree of the indicated BOREAS stand. Each of these measurements represents the arithmetic mean of three samples taken at the same location in that tree. For a given tree, a measurement series represents the relative dielectric constant as a function of depth into the tree trunk.

\subsection{Discussion}

The dielectric constant of woody vegetation varies dramatically as the vegetation transitions from a frozen to a thawed state. Because radar backscatter responds to changes in dielectric constant, these measurements were obtained to verify that the trees had undergone the spring thaw transition.

The relative dielectric constant was measured as a function of depth into the trunks of three trees in each of seven BOREAS tower sites. An Applied Microwave Corporation C-band field PDP was used to measure these data. Profiles were obtained during April 1994, shortly after the trees thawed.

\subsection{Related Data Sets}

BOREAS RSS-15 SIR-C and Landsat TM Biomass and Landcover Maps

BOREAS RSS-16 Level-3b DC-8 AirSAR CM Images

BOREAS RSS-16 Level-3b DC-8 AirSAR SY Images

BOREAS RSS-17 Stem and Air Temperature Measurements

BOREAS RSS-17 1994 ERS-1 Level-1 Backscatter Change Images

BOREAS RSS-17 Xylem Flux Density Measurements at the SSA-OBS Site

\section{Investigators}

\subsection{Investigator(s) Name and Title}

Principal Investigator

Dr. JoBea Way

Jet Propulsion Laboratory

Co-Investigator

Dr. Kyle McDonald

Jet Propulsion Laboratory

Dr. Reiner Zimmermann

Bayreuth Institute for Terrestrial Ecosystem Research (BITOEK) 


\subsection{Title of Investigation}

Monitoring Environmental and Phenologic State and Duration of State with SAR as Input to Improved $\mathrm{CO}_{2}$ Flux Models

\subsection{Contact Information}

\section{Contact 1:}

Dr. JoBea Way

Jet Propulsion Laboratory

Mail Stop 300-233

California Institute of Technology

4800 Oak Grove Drive

Pasadena, CA 91109

(818) 354-8225

(818) 354-9476 (fax)

way@lor.jpl.nasa

\section{Contact 2:}

Dr. Kyle McDonald

Jet Propulsion Laboratory

Mail Stop 300-233

California Institute of Technology

4800 Oak Grove Drive

Pasadena, CA 91109

(818) 354-3263

(818) 354-9476 (fax)

kyle.mcdonald@jpl.nasa.gov

\section{Contact 3:}

Dr. Reiner Zimmermann

Bayreuth Institute for Terrestrial Ecosystem Research (BITOEK)

Plant Ecology II

University of Bayreuth

D-95445 Bayreuth

GERMANY

reiner.zimmermann@bitoek.uni-bayreuth.de

\section{Contact 4:}

Jaime Nickeson

Raytheon ITSS

NASA GSFC

Code 923

Greenbelt, Maryland 20771

(301) 286-3373

(301) 286-0239 (fax)

Jaime.Nickeson@gsfc.nasa.gov

\section{Theory of Measurements}

The relative dielectric constant is monitored with an Applied Microwave Corporation field PDP. The PDP used here measures the complex reflection coefficient (magnitude and phase) at the point of contact between a material of unknown dielectric constant and a semirigid coaxial probe tip. The reflection coefficient was measured at a frequency of $5 \mathrm{GHz}$, corresponding to the C-band portion of 
the electromagnetic spectrum. The real and imaginary parts of the relative dielectric constant are determined from the complex reflection coefficient through application of a calibration equation

determined from measurements of reflection coefficient made on a series of reference dielectric liquids.

\section{Equipment}

\subsection{Sensor/Instrument Description}

The dielectric constant was measured with a field PDP manufactured by Applied Microwave Corporation, Lawrence, KS. These instruments are no longer in production.

\subsubsection{Collection Environment}

Data were collected in April 1994. Air temperature was above $0{ }^{\circ} \mathrm{C}$. Weather conditions varied from cool and clear to rainy.

\subsubsection{Source/Platform}

The PDP is a hand-held, field portable device.

\subsubsection{Source/Platform Mission Objectives}

This study was undertaken to combine ERS-1 SAR with ecosystem $\mathrm{CO}_{2}$ flux models. The objective is to use SAR observations as direct inputs to these models to improve their estimates of seasonal $\mathrm{CO}_{2}$ flux.

\subsubsection{Key Variables}

Relative dielectric constant (C-band).

\subsubsection{Principles of Operation}

The PDP provides a direct measurement of the complex reflection coefficient. The relative dielectric constant is inferred through application of a calibration transformation equation determined from an equivalent circuit model applied to the coaxial probe tip. The parameters of the calibration transformation equation are determined from measurements taken on a series of liquids of known dielectric constant.

\subsubsection{Sensor/Instrument Measurement Geometry}

The dielectric constant was inferred from measurements of the complex reflection coefficient measured at the interface of a $0.358 \mathrm{~cm}(0.141 \mathrm{inch})$ diameter semirigid coaxial probe tip and with an unknown dielectric constant, the tree trunk.

\subsubsection{Manufacturer of Sensor/Instrument}

Applied Microwave Corporation

Lawrence, KS

The PDP is no longer in production.

\subsection{Calibration}

Calibration and processing of the dielectric data were performed with Mathematica 2.0 for the Macintosh (Wolfram Research, Inc.). The calibration technique is described in the PDP manual (1989) and by Dobson (1990).

\subsubsection{Specifications}

None given.

\subsubsection{Tolerance}

None given. 


\subsubsection{Frequency of Calibration}

Calibration against a series of dielectric liquids was performed in the laboratory at the Jet Propulsion Laboratory (JPL) shortly before going to the BOREAS sites in April. In-field calibration checks are performed against an air standard immediately before each dielectric measurement.

\subsubsection{Other Calibration Information \\ Not available.}

\section{Data Acquisition Methods}

Profiles of the relative dielectric constant were obtained for each tree by drilling a small hole in the tree trunk to the desired depth, measuring the depth of the hole with a caliper, inserting the coaxial probe tip, and measuring the complex reflection coefficient. The process is repeated in the same hole, drilled successively deeper, until a point near the center of the tree trunk is reached, or until the probe tip cannot be inserted any further. Data are stored in a hand-held computer and loaded onto a PC for postprocessing. A series of three measurements was obtained at each depth. The values for the relative dielectric constant provided in the data file were computed by averaging the three values of dielectric constant obtained from these measurements.

\section{Observations}

\subsection{Data Notes}

The time values for the SSA-OA site on 19-April do not change except for the last few record on that day. The clock on the calculator was not set properly. The measurements acquired at time $=14.00$ (20:00 Greenwich Mean Time (GMT)) were collected at approximately 14:00 +/- 15 minutes according to field notes. The calculator's internal clock was reset to correct the time problem at 14.24 (20:24 GMT). As this data set is not time-critical over the acquisition period of each profile, this will have no effect on the data quality.

\subsection{Field Notes \\ None given.}

\section{Data Description}

\subsection{Spatial Characteristics}

\subsubsection{Spatial Coverage}

Each measurement is taken from one tree within a stand. Groups of three individual trees were measured at the BOREAS tower sites. The following North American Datum of 1983 (NAD83) site locations were sampled in the NSA and SSA:

\begin{tabular}{lccc} 
Site & UTM Zone & UTM Northing $(\mathrm{m})$ & UTM Easting $(\mathrm{m})$ \\
\hline NSA-OBS & 14 & 6192853.4 & 532444.5 \\
NSA-YJP & 14 & 6194706.9 & 544583.9 \\
NSA-OJP & 14 & 6198176.3 & 523496.2 \\
SSA-YJP & 13 & 5969762.5 & 523320.2 \\
SSA-OJP & 13 & 5974257.5 & 520227.7 \\
SSA-OBS & 13 & 5982100.5 & 492276.5 \\
SSA-OA & 13 & 5942899.9 & 420790.5
\end{tabular}




\subsubsection{Spatial Coverage Map}

Not available.

\subsubsection{Spatial Resolution}

The spatial resolution of a given measurement is one tree. A series of records corresponding to a single tree and tower site corresponds to one dielectric profile.

\subsubsection{Projection}

Not applicable.

\subsubsection{Grid Description}

Not applicable.

\subsection{Temporal Characteristics}

\subsubsection{Temporal Coverage}

Data collection took place from 19-April to 28-April-1994.

\subsubsection{Temporal Coverage Map}

The dates when the various sites were measured are:

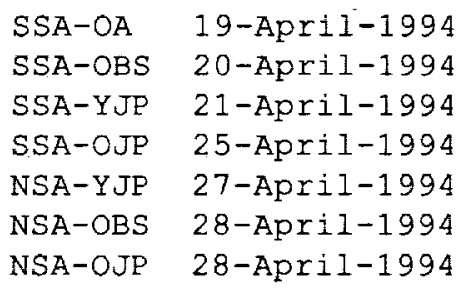

\subsubsection{Temporal Resolution}

One measurement of dielectric constant takes less than 1 minute. Measurements at each tree were taken at 2- to 4-minute intervals. A complete profile series can be completed within 1 hour.

\subsection{Data Characteristics}

\subsubsection{Parameter/Variable}

The parameters contained in the data files on the CD-ROM are

Column Name
SITE_NAME
SUB_SITE
DATE_OBS
TIME_OBS
TREE
TREE_DIAMETER
PROBE_DEPTH
MEAN_DIELECTRIC_CONSTNT_REAL
MEAN_DIELECTRIC_CONSTNT_IMGNRY
CRTECN_CODE
REVISION_DATE




\subsubsection{Variable Description/Definition}

The descriptions of the parameters contained in the data files on the CD-ROM are:

\begin{tabular}{|c|c|}
\hline Column Name & Description \\
\hline SITE_NAME & $\begin{array}{l}\text { The identifier assigned to the site by BOREAS, } \\
\text { in the format SSS-TTT-CCCCC, where SSS identifies } \\
\text { the portion of the study area: NSA, SSA, REG, } \\
\text { TRN, and TTT identifies the cover type for the } \\
\text { site, } 999 \text { if unknown, and CCCCC is the identifier } \\
\text { for site, exactly what it means will vary with } \\
\text { site type. }\end{array}$ \\
\hline SUB_SITE & $\begin{array}{l}\text { The identifier assigned to the sub-site by } \\
\text { BOREAS, in the format GGGGG-IIIII, where GGGGG is } \\
\text { the group associated with the sub-site } \\
\text { instrument e.g. HYD06 or STAFF, and IIIII is the } \\
\text { identifier for sub-site, often this will refer to } \\
\text { an instrument. }\end{array}$ \\
\hline DATE OBS & The date on which the data were collected. \\
\hline TIME_OBS & $\begin{array}{l}\text { The Greenwich Mean Time (GMT) when the data were } \\
\text { collected. }\end{array}$ \\
\hline TREE & $\begin{array}{l}\text { The individual tree from which measurements were } \\
\text { taken. }\end{array}$ \\
\hline TREE_DIAMETER & $\begin{array}{l}\text { The diameter of the tree measured near the probe } \\
\text { insertion point. }\end{array}$ \\
\hline PROBE_DEPTH & $\begin{array}{l}\text { The depth of the sensor probe into the tree } \\
\text { trunk. }\end{array}$ \\
\hline MEAN_DIELECTRIC_CONSTNT_REAL & $\begin{array}{l}\text { The real portion of the relative dielectric } \\
\text { constant, determined through application of a } \\
\text { calibration equation applied to the reflection } \\
\text { coefficient measured by the probe. }\end{array}$ \\
\hline MEAN_DIELECTRIC_CONSTNT_IMGNRY & $\begin{array}{l}\text { The imaginary portion of the relative dielectric } \\
\text { constant, determined through application of a } \\
\text { calibration equation applied to the reflection } \\
\text { coefficient measured by the probe. }\end{array}$ \\
\hline CRTFCN_CODE & $\begin{array}{l}\text { The BOREAS certification level of the data. } \\
\text { Examples are CPI (Checked by PI), CGR (Certified } \\
\text { by Group), PRE (Preliminary), and CPI-??? (CPI } \\
\text { but questionable). }\end{array}$ \\
\hline REVISION_DATE & $\begin{array}{l}\text { The most recent date when the information in the } \\
\text { referenced data base table record was revised. }\end{array}$ \\
\hline
\end{tabular}

\subsubsection{Unit of Measurement}

The measurement units for the parameters contained in the data files on the CD-ROM are:

Column Name

SITE_NAME
SUB_SITE
DATE_OBS
TIME_OBS
TREE
TREE_DIAMETER

PROBE DEPTH
Units
[none]
[none]
[DD-MON-YY]
[HHMM GMT]
[none]
[millimeters]
[millimeters] 


$\begin{array}{ll}\text { MEAN_DIELECTRIC_CONSTNT_REAL } & \text { [unitless] } \\ \text { MEAN_DIELECTRIC_CONSTNT_IMGNRY } & \text { [unitless] } \\ \text { CRTECN_CODE } & \text { [none] } \\ \text { REVISION_DATE } & \text { [DD-MON-YY] }\end{array}$

\subsubsection{Data Source}

The sources of the parameter values contained in the data files on the CD-ROM are:

\begin{tabular}{ll}
\multicolumn{1}{c}{ Column Name } & Data Source \\
\hline SITE_NAME & \\
SUB_SITE & [Assigned by BORIS Staff] \\
DATE_OBS & [Assigned by BORIS Staff] \\
TIME_OBS & [RSS-17 team] \\
TREE & [Hand-held calculator] \\
TREE_DIAMETER & [RSS-17 team] \\
PROBE_DEPTH & [RSS-17 team] \\
MEAN_DIELECTRIC_CONSTNT_REAL & [Caliper] \\
MEAN_DIELECTRIC_CONSTNT_IMGNRY & [Dielectric probe] \\
CRTECN_CODE & [Dielectric probe] \\
REVISION_DATE & [Assigned by BORIS Staff] \\
& [Assigned by BORIS Staff]
\end{tabular}

\subsubsection{Data Range}

The following table gives information about the parameter values found in the data files on the CD-ROM.

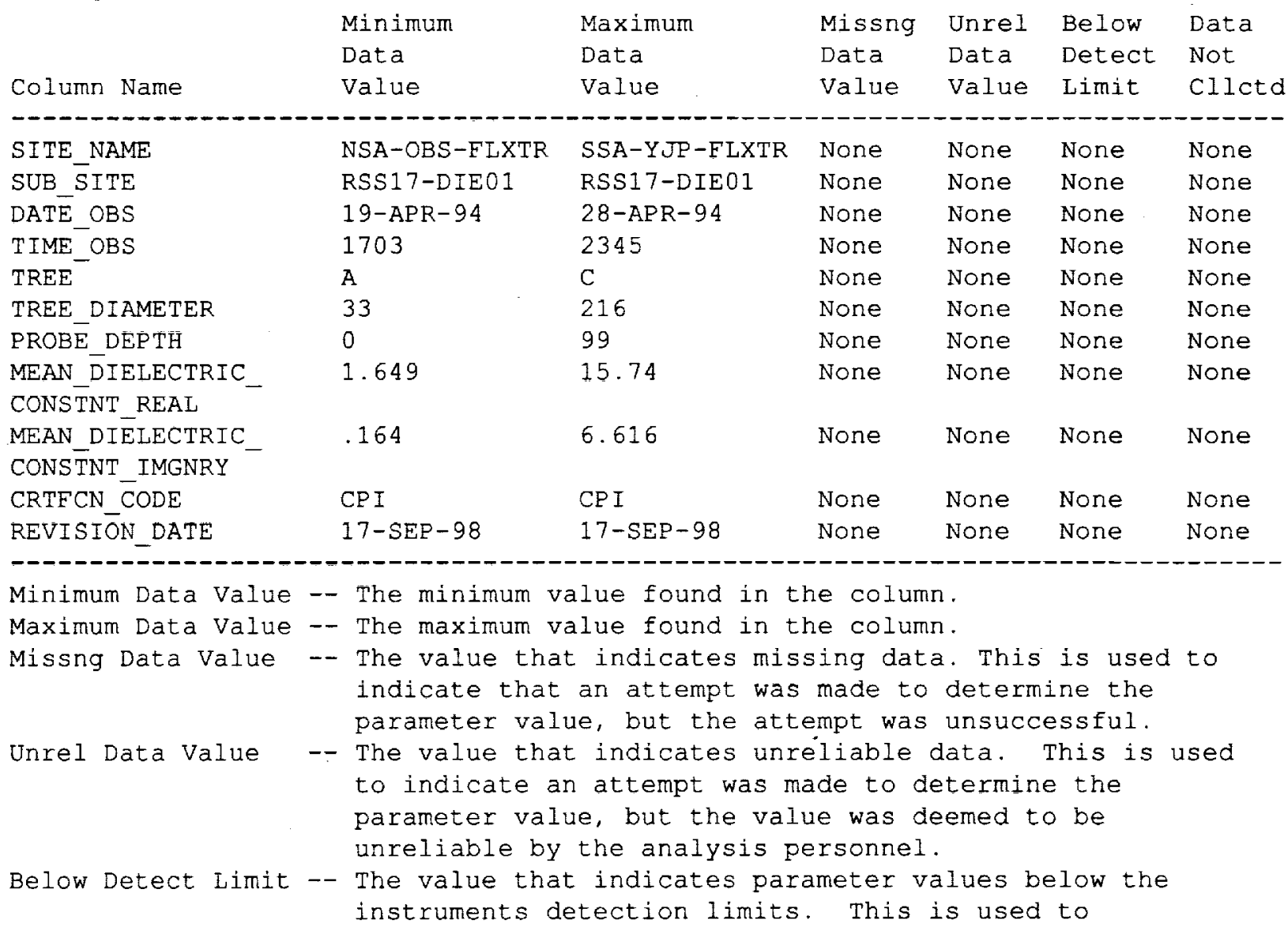




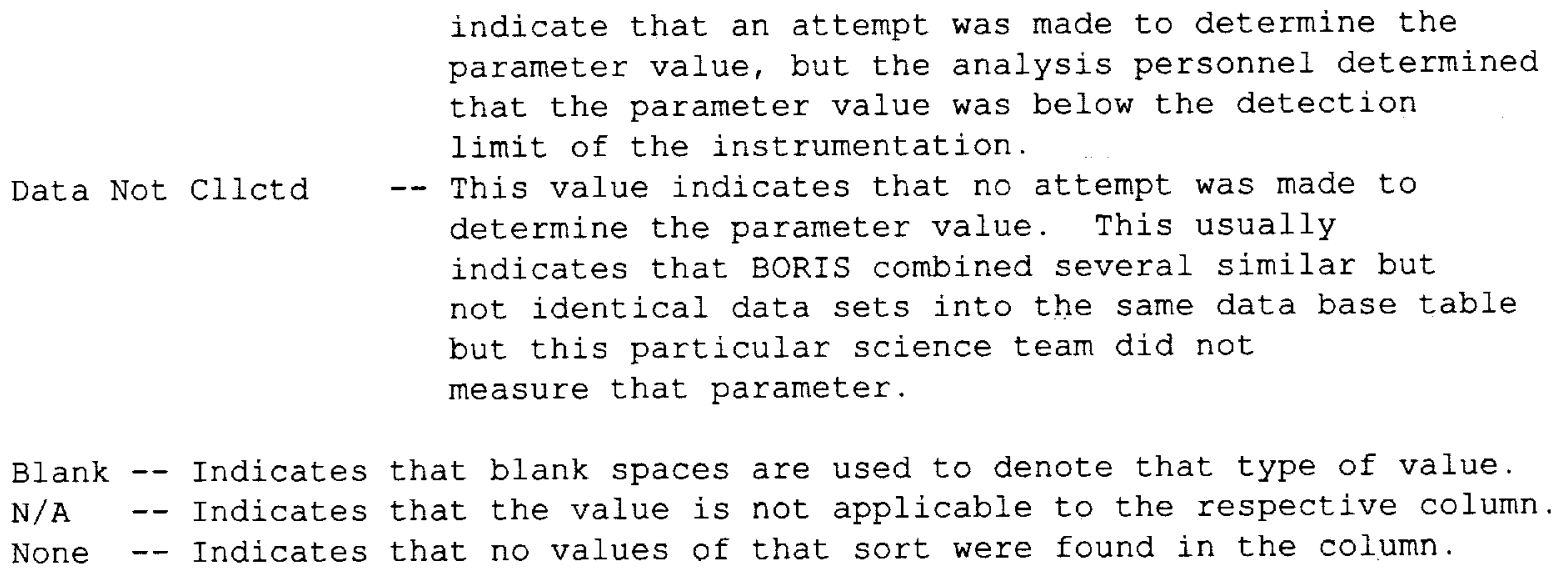

\subsection{Sample Data Record}

The following is a sample of the first few records from the data table on the CD-ROM: SITE_NAME, SUB_SITE,DATE_OBS, TIME_OBS, TREE, TREE_DIAMETER, PROBE_DEPTH, MEAN_DIELECTRIC_CONSTNT_REAL, MEAN̄DIELECTRIC_CONSTNT_IMGNRY, CRTFCN_CODE, REVISION_DATE

'NSA-OBS-FLXTR', 'RSS17-DIE01', 28-APR-94,1703, 'A', 116,0.0,1.714,.242, 'CPI', 17-SQEP-98

'NSA-OBS-FLXTR', 'RSS17-DIE01', 28-APR-94,1705, 'A', 116,3.0,8.367, 5.034, 'CPI', $17-S E P-98$

'NSA-OBS-FLXTR', 'RSS17-DIE01', 28-APR-94, 1708, 'A' , 116,4 0, 8.049,3.259, 'CPI', 17-SEP- 98

'NSA-OBS-FLXTR', 'RSS17-DIE01', 28-APR-94,1710, 'A', 116,5.5,9.644,3.618, 'CPI', $17-S E P-98$

\section{Data Organization}

\subsection{Data Granularity}

The smallest unit of data tracked by BOREAS Information System (BORIS) is all of the measurements for a given site on a given day.

\subsection{Data Format(s)}

The Compact Disk-Read-Only Memory (CD-ROM) files contain American Standard Code for Information Interchange (ASCII) numerical and character fields of varying length separated by commas. The character fields are enclosed with single apostrophe marks. There are no spaces between the fields.

Each data file on the CD-ROM has four header lines of Hyper-Text Markup Language (HTML) code at the top. When viewed with a Web browser, this code displays header information (data set title, location, date, acknowledgments, etc.) and a series of HTML links to associated data files and related data sets. Line 5 of each data file is a list of the column names, and line 6 and following lines contain the actual data. 


\section{Data Manipulations}

\subsection{Formulae}

None given.

\subsubsection{Derivation Techniques and Algorithms}

None given.

9.2 Data Processing Sequence

\subsubsection{Processing Steps}

None given.

\subsubsection{Processing Changes}

Not applicable.

\subsection{Calculations}

\subsubsection{Special Corrections/Adjustments}

Not applicable.

\subsubsection{Calculated Variables}

None given.

\subsection{Graphs and Plots}

Not available.

\section{Errors}

\subsection{Sources of Error}

Instabilities in the electronics of the PDP are taken into account by repeated calibration of the PDP with free space as the calibration standard. Accuracy of the dielectric constant measurement is limited by the range of the dielectric constant of the liquid standards used in laboratory calibration of the PDP.

\subsection{Quality Assessment}

\subsubsection{Data Validation by Source}

None given.

\subsubsection{Confidence Level/Accuracy Judgment}

Accuracy of the dielectric constant is estimated to be $+/-10 \%$ when the real portion, $\operatorname{Re}($ eps), is less than 15 and when the imaginary portion, $\operatorname{Im}(\mathrm{eps})$, is less than 4 . The accuracy of the dielectric constant decreases to $+/-30 \%$ when $\operatorname{Re}(\mathrm{eps})$ is greater than 15 and $\operatorname{Im}(\mathrm{eps})$ is greater than 4 , where eps is the complex relative dielectric constant.

\subsubsection{Measurement Error for Parameters}

Not available.

\subsubsection{Additional Quality Assessments}

Not applicable.

\subsubsection{Data Verification by Data Center}

Data have been checked for content as described and for format. 


\section{Notes}

\subsection{Limitations of the Data}

None given.

\subsection{Known Problems with the Data}

None given.

\subsection{Usage Guidance}

These data are typically used to estimate the gross vegetation dielectric constant for application to radar remote sensing studies (e.g., Way et al., 1997).

\subsection{Other Relevant Information}

Not available.

\section{Application of the Data Set}

These data can be used for site-level observations related to the state of the stand or the forest, either frozen or thawed.

\section{Future Modifications and Plans}

None.

\section{Software}

\subsection{Software Description}

Data collection and preprocessing of the PDP data files were performed with custom software written for the HP hand-held computer at the University of Michigan radiation laboratory. Calibration and processing of the dielectric data were performed with Mathematica 2.0 for the Macintosh (Wolfram Research, Inc.).

\subsection{Software Access}

None given. 


\section{Data Access}

The dielectric constant profile data are available from the Earth Observing System Data and Information System (EOSDIS) Oak Ridge National Laboratory (ORNL) Distributed Active Archive Center (DAAC).

\subsection{Contact Information}

For BOREAS data and documentation please contact:

ORNL DAAC User Services

Oak Ridge National Laboratory

P.O. Box 2008 MS-6407

Oak Ridge, TN 37831-6407

Phone: (423) 241-3952

Fax: (423) 574-4665

E-mail: ornldaac@ornl.gov or ornl@eos.nasa.gov

\subsection{Data Center Identification}

Earth Observing System Data and Information System (EOSDIS) Oak Ridge National Laboratory (ORNL) Distributed Active Archive Center (DAAC) for Biogeochemical Dynamics http://www-eosdis.ornl.gov/ [nternet Link].

\subsection{Procedures for Obtaining Data}

Users may obtain data directly through the ORNL DAAC online search and order system [http://www-eosdis.ornl.gov/] and the anonymous FTP site [ftp://www-eosdis.ornl.gov/data/] or by contacting User Services by electronic mail, telephone, fax, letter, or personal visit using the contact information in Section 15.1.

\subsection{Data Center Status/Plans}

The ORNL DAAC is the primary source for BOREAS field measurement, image, GIS, and hardcopy data products. The BOREAS CD-ROM and data referenced or listed in inventories on the CD-ROM are available from the ORNL DAAC.

\section{Output Products and Availability}

\subsection{Tape Products}

None.

\subsection{Film Products}

None.

\subsection{Other Products}

These data are available on the BOREAS CD-ROM series. 


\section{References}

17.1 Platform/Sensor/Instrument/Data Processing Documentation Applied Microwave Corporation. 1989. Manual for Portable Dielectric Probe. Applied Microwave Corporation. Lawrence, KS.

\subsection{Journal Articles and Study Reports}

Brunfeldt, D.R. 1997. Theory and Design of a Field-Portable Dielectric Measurement System. Proc. of the 1987 International Geoscience and Remote Sensing Symposium. Ann Arbor, MI, May 18-21, pp. 559-563.

Dobson, M.C. 1990. Calibration of field portable dielectric probes for use in radar experiments. Radiation Laboratory Technical Report, May 1990. The University of Michigan, Ann Arbor.

Hogg, E.H., T.A. Black, G. den Hartog, H.H. Neumann, R. Zimmerman, P.A. Hurdle, P.D. Blanken, Z. Nesic, P.C. Yang, R.M. Staebler, K.C. McDonald, and R. Oren. 1997. A comparison of sap flow and fluxes of water vapor from a boreal deciduous forest. Journal of Geophysical Research 102(D24): 28,929-28,937.

Newcomer, J., D. Landis, S. Conrad, S. Curd, K. Huemmrich, D. Knapp, A. Morrell, J. Nickeson, A. Papagno, D. Rinker, R. Strub, T. Twine, F. Hall, and P. Sellers, eds. 2000. Collected Data of The Boreal Ecosystem-Atmosphere Study. NASA. CD-ROM.

Sellers, P. and F. Hall. 1994. Boreal Ecosystem-Atmosphere Study: Experiment Plan. Version 1994-3.0, NASA BOREAS Report (EXPLAN 94).

Sellers, P. and F. Hall. 1996. Boreal Ecosystem-Atmosphere Study: Experiment Plan. Version 1996-2.0, NASA BOREAS Report (EXPLAN 96).

Sellers, P., F. Hall, and K.F. Huemmrich. 1996. Boreal Ecosystem-Atmosphere Study: 1994 Operations. NASA BOREAS Report (OPS DOC 94).

Sellers, P., F. Hall, and K.F. Huemmrich. 1997. Boreal Ecosystem-Atmosphere Study: 1996 Operations. NASA BOREAS Report (OPS DOC 96).

Sellers, P., F. Hall, H. Margolis, B. Kelly, D. Baldocchi, G. den Hartog, J. Cihlar, M.G. Ryan, B. Goodison, P. Crill, K.J. Ranson, D. Lettenmaier, and D.E. Wickland. 1995. The boreal ecosystem-atmosphere study (BOREAS): an overview and early results from the 1994 field year. Bulletin of the American Meteorological Society. 76(9):1549-1577.

Sellers, P.J., F.G. Hall, R.D. Kelly, A. Black, D. Baldocchi, J. Berry, M. Ryan, K.J. Ranson, P.M. Crill, D.P. Lettenmaier, H. Margolis, J. Cihlar, J. Newcomer, D. Fitzjarrald, P.G. Jarvis, S.T. Gower, D. Halliwell, D. Williams, B. Goodison, D.E. Wickland, and F.E. Guertin. 1997. BOREAS in 1997: Experiment Overview, Scientific Results and Future Directions. Joumal of Geophysical Research 102(D24): 28,731-28,770.

Way, J.B., R. Zimmermann, E. Rignot, K. McDonald, and R. Oren. 1997. Winter and spring thaw as observed with imaging radar at BOREAS. Journal of Geophysical Research 102(D24):

$29,673-29,684$.

\subsection{Archive/DBMS Usage Documentation} None. 


\section{Glossary of Terms}

None.

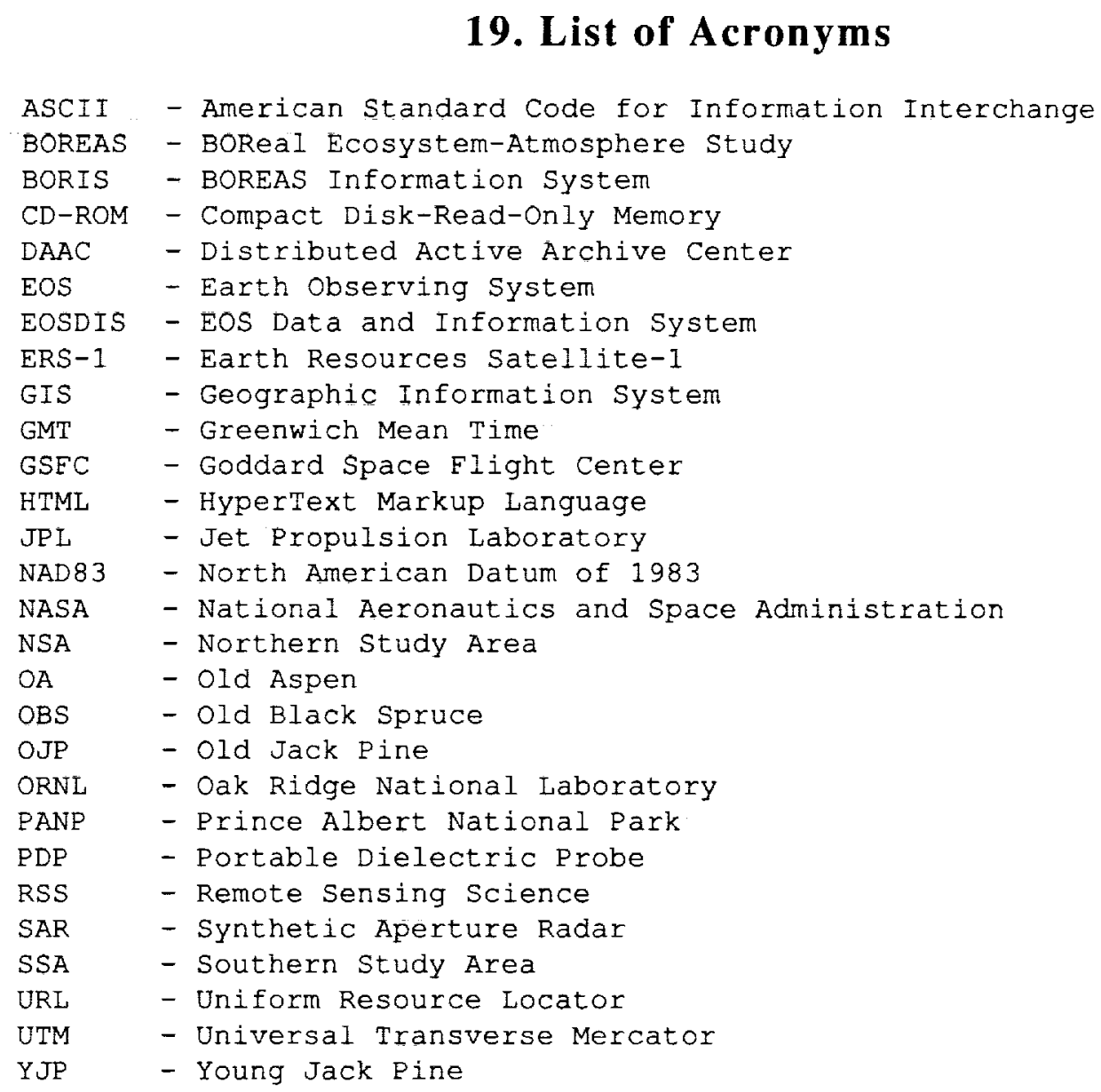

\section{Document Information}

20.1 Document Revision Date(s)

Written: 10-Jun-1997

Last Updated: 06-Aug-1999

20.2 Document Review Date(s)

BORIS Review: 10-Sep-1997

Science Review: 31-Oct-1997

\subsection{Document ID}




\subsection{Citation}

When using these data, please acknowledge K.C. McDonald, J.B. Way, and R. Zimmermann for providing the data and include citations of relevant papers in Section 17.2.

If using data from the BOREAS CD-ROM series, also reference the data as:

Way, J.B., K. McDonald, and R. Zimmermann, "Monitoring Environmental and Phenologic State and Duration of State with SAR as Input to Improved $\mathrm{CO}_{2}$ Flux Models." In Collected Data of The Boreal Ecosystem-Atmosphere Study. Eds. J. Newcomer, D. Landis, S. Conrad, S. Curd, K. Huemmrich, D. Knapp, A. Morrell, J. Nickeson, A. Papagno, D. Rinker, R. Strub, T. Twine, F. Hall, and P. Sellers. CD-ROM. NASA, 2000.

Also, cite the BOREAS CD-ROM set as:

Newcomer, J., D. Landis, S. Conrad, S. Curd, K. Huemmrich, D. Knapp, A. Morrell, J. Nickeson, A. Papagno, D. Rinker, R. Strub, T. Twine, F. Hall, and P. Sellers, eds. Collected Data of The Boreal Ecosystem-Atmosphere Study. NASA. CD-ROM. NASA, 2000.

\subsection{Document Curator}

\subsection{Document URL}




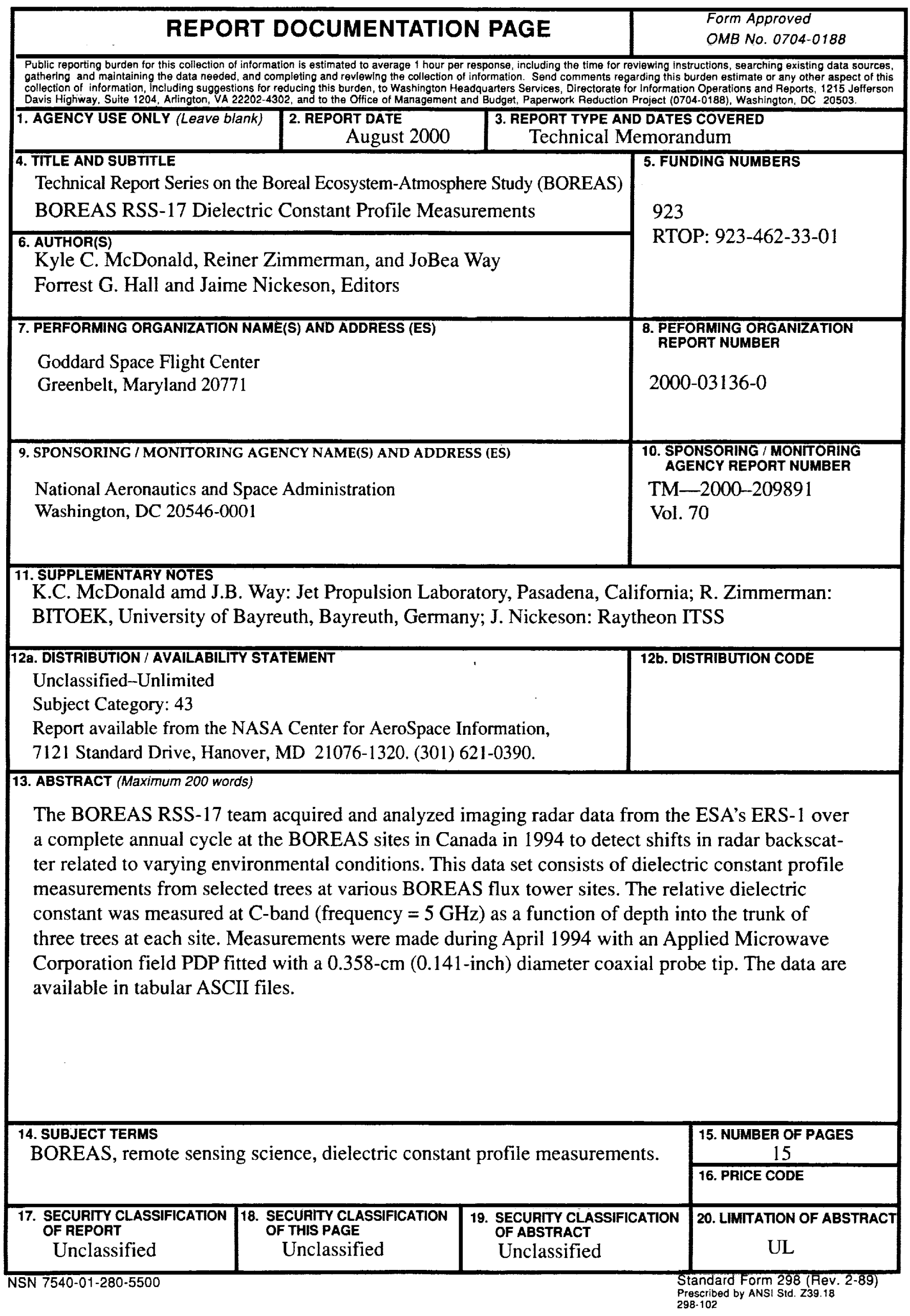

